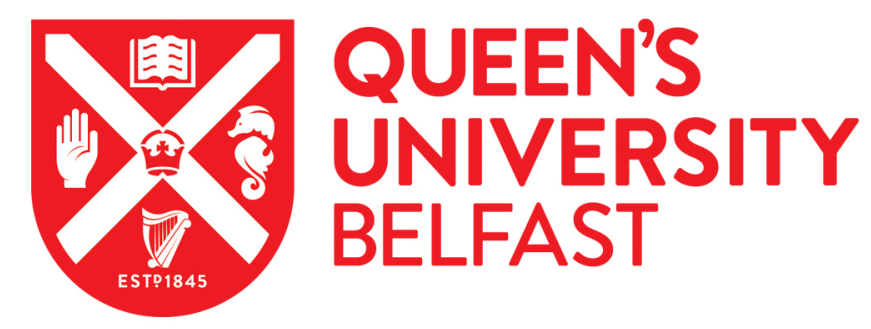

\title{
Does monitoring without enforcement make a difference? The EU and anti-corruption policies in Bulgaria and Romania after accession
}

\author{
Lacatus, C., \& Sedelmeier, U. (2020). Does monitoring without enforcement make a difference? The EU and \\ anti-corruption policies in Bulgaria and Romania after accession. Journal of European Public Policy. \\ https://doi.org/10.1080/13501763.2020.1770842
}

Published in:

Journal of European Public Policy

Document Version:

Peer reviewed version

Queen's University Belfast - Research Portal:

Link to publication record in Queen's University Belfast Research Portal

Publisher rights

Copyright 2020 T \& F. This work is made available online in accordance with the publisher's policies. Please refer to any applicable terms of use of the publisher.

\section{General rights}

Copyright for the publications made accessible via the Queen's University Belfast Research Portal is retained by the author(s) and / or other copyright owners and it is a condition of accessing these publications that users recognise and abide by the legal requirements associated with these rights.

Take down policy

The Research Portal is Queen's institutional repository that provides access to Queen's research output. Every effort has been made to ensure that content in the Research Portal does not infringe any person's rights, or applicable UK laws. If you discover content in the Research Portal that you believe breaches copyright or violates any law, please contact openaccess@qub.ac.uk. 


\title{
Does monitoring without enforcement make a difference? The European Union and anti-corruption policies in Bulgaria and Romania after accession.
}

\author{
Corina Lacatus and Ulrich Sedelmeier
}

\begin{abstract}
The European Union (EU) has made progress with fighting corruption a condition for membership, but it does not have legal instruments to sanction non-compliance once a country has joined. The Cooperation and Verification Mechanism (CVM) was an institutional experiment to compensate the loss of sanctioning power after accession with continued monitoring. Most commentators dismiss the potential of such monitoring without enforcement to foster compliance, but we currently lack an empirical basis to assess this claim. This article's original coding of the CVM reports with regard to corruption control in Romania and Bulgaria provides such a basis. It suggests that monitoring can have a positive impact on state compliance even without material sanctions: despite the low expectations in the literature, compliance in Romania was significantly better than in Bulgaria. We explain Romania's better compliance record with successful domestic institutionbuilding. In contrast to Bulgaria, Romania created strong domestic anti-corruption institutions that served as a powerful institutional base for the fight against corruption. The CVM had a direct effect on institutionbuilding by requiring the establishment of institutions. As these institutions remain vulnerable to governmental obstruction, the CVM has also had an important indirect effect as a social constraint on such obstruction, and as a focal point for societal mobilization against curbing the power of anti-corruption institutions.
\end{abstract}

Keywords conditionality, corruption, European Union, monitoring, Romania, sanctions

\section{Introduction}

The European Union (EU) has been generally successful in using accession conditionality to influence domestic change across a broad range of issues in the candidate countries, as the incentive of membership generally outweighed governments' domestic adjustment costs 
(Grabbe 2006; Kelley 2004; Schimmelfennig and Sedelmeier 2004; 2005; Vachudova 2005). After accession, the incentive structure becomes much less favourable for compliance (Epstein and Sedelmeier 2008; Sedelmeier 2008). The loss of EU leverage is particularly salient in issue areas - such as corruption control - that were subject of accession conditionality but have no basis in EU law. In such areas, EU institutions cannot use material sanctions to enforce compliance in its member states. Therefore, the EU became particularly concerned about the persistence of severe problems with corruption in Bulgaria and Romania on the eve of their accession. To preserve some post-accession influence on those issues, the EU created the 'Cooperation and Verification Mechanism' (CVM). It consists of semi-annual reports on a country's performance in three areas that were particularly problematic: reform of the judiciary, fight against corruption and, in the case of Bulgaria, organised crime. The CVM is primarily a monitoring instrument, not a tool to enforce compliance: the assessment of compliance is not linked to sanctions. The CVM was thus a novel attempt to compensate for the loss of postaccession leverage through continued monitoring without recourse to material sanctions for non-compliance.

Most analyses suggest that the CVM is ineffective (a rare exception is Spendzharova and Vachudova 2012). Such criticism focuses mainly on its apparent inability to diminish corruption in the two countries. Critics typically attribute this lack of impact on corruption to unfavourable domestic conditions, such as deeply engrained cultural legacies of postcommunist societies, but also to shortcomings of the CVM's design, including inappropriate recommendations, inconsistent application, and a lack of focus on practical application (see e.g. Dimitrov et al. 2014, Ganev 2013; Papakostas 2012; Mendelski 2012; Tanasoiu and Racovita's 2012; Toneva-Metodieva 2014). One crucial design flaw of the CVM that these sceptical analyses identify is its lack of enforcement powers (Gateva 2015). 
Although these sceptical assessments provide nuanced insights into the shortcomings of the CVM, they might conclude too readily that monitoring without enforcement cannot have an impact on domestic change. By focusing exclusively on goal-achievement - the extent of corruption on the ground - these studies neglect the question whether the CVM has an impact on eliciting compliance. Although the CVM ultimately needs to be judged indeed against its impact on corruption, the extent to which the CVM is able to induce states to conform to the demands and recommendations made in the CVM reports is a more direct indicator of its behavioural impact. In this regard, research on international governance offers reasons for optimism that monitoring alone can have an impact on compliance (Kelley and Simmons 2015). The CVM largely meets the main conditions that are conducive for monitoring to generate social pressure that can lead to policy change (2015: 55, 59; see also Sedelmeier 2017: 343-5): it is systematic, broadly comparative, wielded by a respected actor (the EU, which enjoys strong support in both countries), and is widely disseminated. Yet currently we lack an empirical basis to assess the CVM's impact on compliance.

One key contribution of the article is that it provides more systematic data about compliance with the CVM. We present the results of a comprehensive coding of the CVM reports' assessment of compliance with the EU's demands and recommendations for the fight against corruption in Bulgaria and Romania from 2007 to 2018. Given the generally negative assessments of the CVM, the main empirical finding is a surprisingly positive compliance record for Romania, especially in comparison to Bulgaria, where conditions for compliance with anti-corruption demands are either similar or more favourable. The second key contribution of our article is then to push back against the received wisdom that monitoring cannot work without the threat of material sanctions, and to explain why the CVM did have an impact in Romania. 
We focus on the broad trend suggesting that compliance is generally better in Romania than Bulgaria. To explain this outcome, we use a most similar systems design. Comparative descriptive statistics show that general explanations for cross-country variation in compliance with corruption control - such as EU incentives, domestic adjustment costs, the strength of domestic civil society, attitudes towards the EU, and party-politics - do not vary across the two countries (or are more favourable in Bulgaria). We argue that the key factor that varies across the two countries and explains the better compliance record in Romania is domestic institutionbuilding. For the case of Bulgaria, we rely on existing studies that indicate that anti-corruption institutions in Bulgaria remained weak. For Romania, we conducted interviews during fieldwork, which suggest that the CVM supported the creation of - in principle - strong institutions, including the National Anticorruption Directorate, the National Integrity Agency, and Anticorruption Service in the Ministry of Regional Development. A new generation of young, motivated and well-trained public officials has used these institutional powers effectively in the fight against corruption. We suggest that the role that the CVM played in the process was two-fold. First, it had a direct impact on institution-building by requiring Romania to establish a National Integrity Agency. Second, it had an indirect impact on institutionbuilding by serving as a social constraint on attempts by the government to curtail domestic anti-corruption institutions, and as a focal point for societal mobilization.

The next section presents the results of our coding of the CVM reports' assessment of compliance that suggests that compliance in Romania is better than in Bulgaria. Section 3 shows that the main explanatory factors for compliance do not vary significantly across the two countries or are less, rather than more, favourable for compliance in Romania. Section 4 suggests that domestic institution-building explains the differences in compliance. It presents the findings from interviews in Romania that suggest that domestic institution-building was more successful than in Bulgaria, and discusses the role of the CVM in the process. Section 5 
demonstrates that the better compliance with the CVM in Romania than in Bulgaria has also started to be manifest in divergent outcomes with regard to improvements of corruption control.

\section{Compliance with the CVM's recommendations}

To obtain a more systematic and empirically grounded understanding of compliance with the CVM, we code the CVM reports' assessment of the two countries' compliance from 2007 to 2018. First, for each of the reports, we identified the specific demands and recommendations for fighting corruption formulated by the Commission and for which it assessed the progress made. We focus on the assessment of the extent to which each of these individual demands have been met, as indicators of compliance. In total, across all reports from 2007 to 2018 , we identified 862 instances of assessments of compliance with the various demands and recommendations: 353 for Bulgaria and 509 for Romania (for more detail on the coding, see Sedelmeier and Lacatus 2016: 10, and the online appendix).

Our coding of the CVM reports' assessment of compliance is a categorical variable measured on a scale from $0-3$, with 0 indicating an area of concern or no progress; 1 denotes little or insufficient progress; 2 denotes some progress; and 3 denotes very good progress or complete implementation of the EU's demands and recommendations. Generally, the inclusion of specific demands in the CVM reports does not follow a systematic pattern. The broader 'benchmarks' that the Commission identified with regard to corruption control remain the same across the years in each country. These benchmarks are (1) the fight against high-level corruption; and (2) within local government (for both countries), while Romania has an additional third benchmark: establishment of an integrity agency. Yet within each of the benchmarks, the Commission dropped some individual demands from the CVM reports permanently when full compliance was achieved, while it maintained other demands in subsequent CVM reports to praise full compliance. Moreover, there is fluctuation in the 
attention specific demands receive in the reports, which is linked to the issues that are considered important at the time of reporting, either by government institutions or by civil society organisations consulted by the CVM staff.

Figure 1 is a graphical presentation of the compliance patterns with regard to the anti-corruption demands in the CVM for the two countries. We first calculated for each report average scores for each of the anti-corruption 'benchmarks', based on the scores for each indicator covered in the report for a specific benchmark. We then calculated the overall score for each report as the averages of the scores for the benchmarks (rather than of all individual indicators across benchmarks). The annual scores average the scores of reports published during that year.

We certainly should not overstate the extent to which our coding is a precise measurement of compliance, and of its variation across issues and over time. However, it does allow us to capture one key trend, in particular with regard to cross-country variation in compliance: overall, compliance in Romania appears surprisingly good, and consistently better than in Bulgaria (notwithstanding a recent deterioration in Romania and improvement in Bulgaria). A better compliance record in Romania than in Bulgaria appears puzzling. As the following section shows, the main explanatory factors identified in the literature either do not vary significantly across the two countries or are more favourable in Bulgaria.

\section{[Figure 1 near here]}

\section{Predominant explanations for compliance with EU anti-corruption demands}

Studies of EU conditionality and of its domestic impact in member states and candidate countries typically emphasise explanatory factors both at the international and the domestic level. The former relates to the EU's use of specific instruments and strategies to influence 
domestic change. Domestic politics in the target countries concerns domestic adjustment costs for governments and constituencies that benefit from changes that the EU demands (Schimmelfennig and Sedelmeier 2004, 2005; Jacoby 2006; Kelley 2004; Vachudova 2005).

\section{EU incentives and social pressure}

The material incentive structure of the CVM is very weak (Gateva 2015). The only sanction is the possibility for other member states not to recognise and execute decisions by Bulgarian or Romanian courts. Although non-compliance with the CVM cannot be used to withhold EU funding, instances in which funds were frozen because of fraud might create the perception that the CVM can wield material sanctions. For example, in 2008 Bulgaria lost a total of $€ 520 \mathrm{~m}$ in EU funding: $€ 300 \mathrm{~m}$ in July for contracts frozen by the Commission due to suspected fraud and $€ 220 \mathrm{~m}$ in November for unallocated funds after the Commission did not renew the accreditation of government agencies responsible for disbursing the funds, investigated by the EU's antifraud agency (Hope and Troev 2008). However, these measures were not (and indeed cannot) be used as a punishment with regard to non-compliance with general CVM demands. Instead, they were due to specific issues of misappropriating funds, which the EU can apply in all member states.

The lack of material incentives that the CVM attaches to compliance implies that there is little variation with regard to the EU level that can explain cross-country differences. In practice, there may be a variation over time in the EU's ability to use material incentives for compliance through issue-linkage. From 2010, a number of member states explicitly made their approval of the accession of Bulgaria and Romania to the Schengen treaty (which requires unanimity) dependent on progress with the CVM. The Commission - and the countries concerned denounced the issue-linkage as illegitimate since Schengen accession had its own set of conditions that the Commission had judged the countries to have met. Still, even if the issue- 
linkage had not been collectively agreed, from 2010, material incentives were de facto attached to compliance with the CVM. While issue-linkage to Schengen membership might be in line with improvements of compliance in both countries over time after 2010, the lack of variation in EU incentives cannot explain why compliance in Romania is better.

Monitoring without enforcement largely relies on social pressure to elicit compliance (Kelley and Simmons 2015; Sedelmeier 2014: 113-18). Its effectiveness depends on both international and domestic factors (Schimmelfennig and Sedelmeier 2005: 18-20; Sedelmeier 2017: 343-5). Since the legitimacy of the CVM depends on a consistent application by the EU according to a set of general rules, its selective use for Romania and Bulgaria damages its legitimacy. It does not apply to all member states, nor was it applied to Croatia when it joined in 2013. Likewise, while the issue-linkage to Schengen membership should be welcome from an incentive-based perspective, it is detrimental from a legitimacy perspective. Since this linkage was neither foreseen in the agreed rules on the CVM nor on Schengen accession, it is a case of 'hostage taking' that threatens negative consequences in an unrelated issue area and thus decreases the legitimacy of the CVM.

The domestic conditions for social pressure are similarly conducive in Bulgaria and Romania. For successful social pressure, the recommendations of the CVM must resonate positively with domestic norms and political culture, and the EU as the rule-setting institutions must enjoy a high degree of normative legitimacy. Although public opinion about EU membership has become less favourable over time in both countries, and net support for EU membership was stronger in Romania at the start of EU membership, these differences are not large and public support remained high in both countries (Figure 2). Attitudes of government parties have remained strongly positive at similar levels in both countries since accession, if not slightly more positive in Bulgaria (Figure 3). Moreover, a Flash Eurobarometer $(2015$ : 38, 42) survey 
shows that in both countries the population also strongly endorses specifically the continuation of the CVM (73\% in Romania, $78 \%$ in Bulgaria).

[Figure 2 near here]

\section{[Figure 3 near here]}

In sum, while the conditions for compliance with the CVM may be unfavourable in view of the lack of enforcement, they are more favourable with regard to social pressure, due to the legitimacy that the EU enjoys in both countries. At the same time, the similarity of conditions suggests that neither can explain the variation in compliance across countries.

\section{Domestic adjustment costs}

The main costs of compliance with EU demands in the CVM arise for governments since the beneficiaries of corrupt activities are typically public officials. One key indicator of adjustment costs is the status quo with regard to levels of corruption: the higher pre-existing levels of corruption, the costlier are measures to reduce it for governments. Again, there is little variation between Romania and Bulgaria: according to the Worldwide Governance Indicators for corruption control, the two countries had identical scores when entering the EU (and the CVM) in 2007 (see also figure 6 below).

Governments' cost of compliance with anti-corruption measures might also depend on their partisan orientation, which can make them more or less prone to corruption. Kartal (2014: 950, 953) argues that governments favouring 'Soviet-type economic policies' (government control and trade protectionism) rather than liberal market economies have a negative impact on corruption control after EU accession, as 'a less competitive economy increases opportunities 
for rent seeking and decreases official accountability' (Kartal 2014: 950). Spendzharova and Vachudova (2012) explain the EU's impact on anti-corruption policy primarily in terms of party politics, focusing on the salience of the fight against corruption in parties' platforms (2012: 47). Parties competing in elections on a commitment to fighting corruption stake their credibility on their ability to deliver once in office. Spendzharova and Vachudova (2012: 49-50) thus argue that Bulgaria made greater progress with fighting corruption largely due to a new centre-right party - GERB - gaining office on an anti-corruption platform in 2009, while in Romania the main government and opposition parties formed a 'political cartel that benefits from institutional stasis and corruption' (2012: 55). Very specifically, they expected that 'should the PSD [Social Democratic Party] control the next government, corruption will deepen.' (2012: $55)$.

Yet again, the focus on party politics does not fit well with the patterns of compliance across the two countries. With regard to governments' Left/Right orientation, conditions for compliance were not more favourable in Romania than in Bulgaria. If anything, since 2007, Romania had overall more governments with a Centre-Left orientation (figure 4), yet compliance continued to improve further although the PSD indeed obtained office in 2012. Party politics thus also cannot explain the better compliance record in Romania.

\section{[Figure 4 near here]}

Compliance with EU demands may entail adjustment costs for governments, but there are also domestic groups that benefit from compliance with the CVM and may put pressure on governments to comply. Since the CVM does not entail material incentives for government compliance, domestic groups benefiting intrinsically from the domestic changes that the EU 
demands become particularly important for compliance (Spendzharova and Vachudova 2012; Mungiu-Pippidi 2008).

The main beneficiaries and proponents of anti-corruption policies recommended by the CVM are diffuse groups of citizens, anti-corruption NGOs and independent media and investigative journalists that can mobilise public opinion, which in turn can increase electoral pressure on political parties. A strong civil society and free media increase the likelihood that voters will reward parties for tying their electoral campaigns to fighting corruption, and that they will punish them for failing to deliver. However, in both Romania and Bulgaria, these conditions are rather unfavourable (compared to other democracies), both with regard to civil society, and, especially, with regard to the independence of the media. And crucially for our purposes, neither vary much across the two countries (figure 5).

\section{[Figure 5 near here]}

While the main explanatory factors suggested by the literature thus do not vary across the two countries, there is an important difference with regard to a domestic factor that is often neglected in studies of compliance with EU conditionality: facilitating domestic institutions that have a mandate that is in line with the goals of international rules (Börzel and Risse 2003). Although the anti-corruption literature finds that the existence of a dedicated anti-corruption institution does not lead to significantly better performance (Mungiu-Pipidi 2013: 41), the following section suggests that variation with regard to domestic anti-corruption institutions explains the differences in compliance across the two countries. It is beyond the scope of this article to explain why the two countries differ with regard to domestic institutions (as opposed to the effect that these differences have on compliance). However, our observation resonates with the argument by Schoenman (2014) that differences in the networks linking politicians 
and business elites account for generally weaker institutional development in Romania and Bulgaria compared to other post-communist countries, while the domination of Bulgarian parties by business elites resulted in even weaker institutions than in Romania.

\section{Domestic institution-building and compliance with the CVM anti-corruption provisions}

Domestic institution-building for the fight against corruption succeeded to a greater extent in Romania than in Bulgaria. Prior to EU accession, Bulgaria established a number of institutional bodies with a mandate to combat corruption, but they are generally considered ineffective (Institute for Public Policy 2010, Dimitrova 2015). These institutions consisted of ministerial inspectorates and two bodies in the Council of Ministers: a Chief Inspectorate and the Commission on Prevention and Combating of Corruption, established in 2006 as the main anticorruption institution. However, these institutions 'failed to make a strong start in using their prerogatives and were weakened by the unwillingness of politicians to appoint strong and independent leaders for them' (Dimitrova 2015:20). In December 2017, the Bulgarian parliament passed legislation that established a new single anti-corruption institution from the various previously existing institutions, the Commission for Counteracting Corruption and for Seizure of Illegally Acquired Property. While this new institution has been mired in political conflict, its creation acknowledged the shortcomings of the existing institutional infrastructure.

\section{Domestic institution-building in Romania}

Domestic institution-building in Romania shows a more positive picture than in Bulgaria. Interviews with a diverse group of interviewees from NGOs, academic institutions, public officials, and investigative journalists suggest that Romania successfully created - in principle - strong anti-corruption institutions that have served as an institutional base for a new generation of young, motivated and well-trained public officials to fight corruption. Their 
impact remains vulnerable to cross-party attempts in parliament to impede anti-corruption activities. In the face of this threat, the CVM acted primarily as a constraint on open obstruction due to the high legitimacy that the EU - and by extension the CVM - enjoy in public opinion (and among elites).

Interviewees generally agree that the areas where progress with compliance has been strongest relate to institutional development: the creation of the National Anticorruption Directorate (DNA), which investigates and prosecutes corruption cases, and of the National Integrity Agency (ANI), which has substantial powers to force public officials to declare their assets and conflicts of interests, and to seize unexplained assets. In turn, the creation of these institutions has enabled progress with compliance with regard to high-level corruption cases, which had been very limited until 2010. Another important institutional development was the creation in 2012 of an Anticorruption Service in the Ministry of Regional Development to focus on corruption at the local level.

Interviewees identify a number of factors that account for the DNA's increasingly active role. Founded in 2002 as the National Anticorruption Prosecution Office (PNA), its mandate changed around 2007 as a result of the activism of Monica Macovei as Minister of Justice and the support of the government at the time. DNA prosecutors act independently and are not subordinated to any political body, having 'magistrate' status. The DNA's activity increased significantly after Laura Codruța Kövesi took on the position of Chief Prosecutor in 2013. In the absence of an institutional model to replicate, institutional learning needed time to take place. Prosecutors earn well, which reduces incentives to leave, promoting continuity and institutional learning, and also makes them less susceptible to political pressure, pressure from the media, and to bribes. Once the institution started to have more success, staff also became more confident about their activity. A generational shift has also strengthened the institution, 
as older staff from the time of the PNA retired and new, younger prosecutors were hired. Although much work on cases was carried out over the years, decisions and sentencing on many cases were only reached by the mid-2010s. Decision time in the courts has also diminished considerably, most likely due to the new Codes (DNA prosecutors do not have the right to present cases in courts, but forward each case to the court prosecutors, causing major delays at various local courts). A critique of the DNA's activity is that assets have not been recovered even after sentences are definitive. The DNA does not have the power to seize assets, but in May 2015, the government approved a bill to establish a National Agency for the Management of Sequestered Goods for this purpose.

In recent years, the DNA has carried out an increasing number of high-profile investigations, leading to charges against high-level public officials. For instance, former Prime Minister Victor Ponta was charged with fraud, tax evasion and money laundering in 2015. The former mayor of Bucharest, Sorin Oprescu, was sentenced in 2019 to five years and four months in prison. In 2016, PSD leader Liviu Dragnea, widely considered the main influence behind the government at the time, was barred from becoming Prime Minister after he received a two-year suspended sentence for attempting to rig a 2012 national referendum on the impeachment of then President, Traian Băsescu. In 2017, the DNA charged Dragnea with embezzlement and he was sentenced in 2018 to three years and six months in prison.

For ANI in particular, interviewees attribute the trend of improving compliance to increased institutional capacity over time. ANI was created in 2007, with a specific CVM benchmark devoted to its establishment. It began with a very small staff without clear direction or settled institutional mode, but subsequently improved transparency and continued to forward cases of asset verification and investigations to prosecution institutions for further legal action. By the end of 2016, ANI finalised over 12,000 investigations, identifying 2,388 cases of 
incompatibilities, conflicts of interests, or significant differences between incomes and assets, and 333 cases of strong suspicion of criminal offence or corruption. ANI moved towards more preventative activities with the implementation of a new program (PREVENT) aimed at preventing conflicts of interest in public procurement. The deterioration of compliance with regard to ANI in the $2010 \mathrm{CVM}$ report resulted from the parliament's attempt to pass legislation limiting ANI's powers and to amend the Penal Code to this end. ANI's activity was suspended for seven months after the Constitutional Court declared many of its activities unconstitutional. After the CVM report in July 2010 was highly critical of these attacks on the ANI, parliament voted to re-establish its powers (see also Spendzharova and Vachudova 2012: 53), albeit still weakening its mandate by limiting the scope of investigations and removing the asset control commissions (see also Dix and Copil 2010). In general, however, the achievements of ANI (and DNA) have led to a significant increase in the public's trust in these institutions.

By contrast, interviewees suggest that progress with compliance has been slower with regard to corruption at the local level, which is somewhat at odds with the compliance scores in the CVM reports. Interviewees attribute the shortcomings to deficient awareness in the population and lack of capacity amongst local officials. At the same time, interviewees deem DNA activity at the local level good, as well as the ANI's, although with limited scope, and the AntiCorruption Directorate (DGA) as regards the police force. A number of interviewees mentioned efforts to promote change at the local level, such as the creation of integrity posts and offices, putting in place of local projects, and an active focus by the Ministry of Regional Development on local level integrity training. However, such change remains slow and does not trickle down easily from Bucharest to the rest of the country. At the same time, it is the activity of the Regional Development Ministry, DNA and ANI that mostly account for improvements in compliance with the CVM's recommendations for the fight against corruption at the local level. 


\section{The role of key domestic actors}

Interviewees generally single out Parliament as a key obstacle to greater compliance and more effective corruption control. This is also directly reflected in the consistently low compliance with the indicator 'parliamentary awareness/support for the anti-corruption fight and integrity issues in particular.' Parliamentarians from the main parties across government and opposition have colluded in constraining anti-corruption efforts. Such obstructions range from removing the activist Minister of Justice, Monica Macovei, in 2007 and DNA Chief, Laura Codruța Kövesi, in 2018 to the onslaught on the activities of ANI in 2010, and continue to make the progress achieved with regard to institution-building precarious. They culminated in 2018 in the passing of a Justice Reform bill that had attracted widespread domestic and international criticism for limiting the independence of prosecutors.

Rather than following party-political dynamics, attempts to obstruct corruption control confirm the existence of a 'political cartel that benefits from institutional stasis and corruption' (Spendzharova and Vachudova 2012: 55), involving parliamentarians from the Democratic Liberal Party (PDL), Social Democratic Party (PSD) and National Liberal Party (PNL). Although the two presidents since 2007 - Traian Băsescu (PDL) and, from 2014, Klaus Iohannis (Christian Liberal Alliance/PNL) - were both very vocal in their anti-corruption stance, their influence is limited, and they were powerless to prevent the removal of Macovei and Codruța Kövesi respectively.

NGOs believe that they played an important role in contributing to the drafting of the CVM reports (at various points and through participation in the annual assessment meetings with Brussels officials). A larger group of NGOs that also include think tanks (Institute for Public Policy; Romanian Centre for European Policies) mentioned submitting suggestions and reports 
with their assessment. Public officials suggest that civil society representatives are 'necessary voices', but do not appear to consider them particularly influential.

According to interviewees, public opinion has played an important role through increasing demand for transparency. The public's knowledge of the CVM has increased over time, also as a result of more visible successful activity of DNA and ANI. Street protests in late 2015 led to the resignation of Prime Minister Ponta, but nationwide demonstrations in February 2017 and in August 2018 were unable to stop the government's attempts to undermine the activity of the DNA and weaken the legal framework for corruption control. The role of the media has been more limited, as media outlets are owned by a small number of media corporations, which are either controlled by politicians or have a clear party-political orientation. The role of investigative journalists has therefore been very important. A few investigative journalists work on anti-corruption in particular, but they can be fairly vocal and are also often commissioned by (international) think tanks for research purposes.

\section{The role of the CVM}

All interviewees acknowledged an important role of the CVM in the fight against corruption, although their views on this role vary. Representatives of civil society and NGOs see the CVM as central to anti-corruption efforts and claim that there would not have been such effort in Romania without the CVM. They also consider the CVM vital to their own existence, as they use references to the reports to put pressure on the political elites and to apply for funding. They are keen for the CVM to remain in place (albeit with more teeth) and to extend it also to other countries, to limit the possibility for politicians to point at its selective use to denounce its legitimacy. 
While civil society representatives tend to see the CVM as an effective shaming mechanism, public officials see it more as providing institutional and legislative templates, as well as indicators that structure their work. Implementation is considered a challenge that national and local institutions carry out more or less successfully. At the same time, civil servants tend to consider the role of the CVM as diminishing over time as the institutional and legal infrastructure is in place. This focus on institution-building in both sets of accounts of the impact of the CVM - as a tool to protect the building and operation of institutions (through shaming to constrain obstruction) and as template for institution-building - also explains why some interviewees suggest that the CVM's impact is far greater on the elite in Bucharest than on local practices.

Interviewees broadly agree that creating material incentives for compliance with the CVM through the link to the accession to Schengen has not had much impact. While it might have initially increased pressure on the government to comply, this pressure was ineffective. Instead, it fuelled opposition against pressure from the EU and allowed the government to deflect criticism of its compliance record by denouncing the legitimacy of the CVM.

In sum, what explains the better-than-expected compliance with the CVM in Romania is the successful building of domestic institutions that have over time also become effective in carrying out their activities, primarily with regard to high-level corruption. With regard to corruption at the local level, institution-building has also made progress, although here compliance has been more limited. Institution-building and institutional operation is still fragile and remains vulnerable, in particular to obstruction from parliamentarians from across the political spectrum. Although societal mobilization around anti-corruption has increased significantly, it has not led to punishing corrupt politicians at the ballot box - with the exception 
of the surprise victory in the 2014 Presidential election of Klaus Iohannis on an explicit anticorruption platform, and more recently in the 2019 European Parliament elections.

The role of the CVM has been important in explicitly mandating institution-building, mobilizing and legitimizing civil society pressure, and constraining efforts to roll back institution-building. However, the CVM does not owe this impact to the acquisition of material leverage, although some member state governments have linked compliance with the CVM to the prospect of lifting their veto on Romania's and Bulgaria's accession to Schengen. Instead, the CVM has mainly operated as an instrument of social pressure due to the strong legitimacy enjoyed by the EU among elites and publics. Yet precisely this reflected legitimacy of the CVM is threatened not only by its selective use in the two countries but also through the questionable issue-linkage to Schengen accession that is neither envisaged in the rules of Schengen nor in the CVM.

\section{The link between compliance with the CVM and actual levels of corruption}

An analysis of compliance with the CVM reports is relevant in its own right to understand better the scope of EU influence on domestic anti-corruption measures. At the same time, we have to be careful not to overstate the extent to which compliance with the CVM translates into actual improvements of corruption control on the ground. Much of the criticism of the CVM focuses precisely on its lack of influence on corruption levels in the two countries. Yet while corruption remains a serious problem in both countries, a link between compliance with the CVM and improvements in actual corruption levels has become more discernible. Corruption control in Romania has become distinctly better than in Bulgaria (Figure 6), with a certain time-lag that appears consistent with the focus on institution-building that is not immediately reflected in corresponding improvements of corruption control, but takes longer to affect changes on the 
ground. At the same time, corruption control still lags far behind other post-communist EU member states.

\section{[Figure 6 near here]}

Evaluations of the CVM then depend on the counterfactuals employed (see also Dimitrova 2015). If assessed against the yardstick of a far-reaching governance reform that entails the fundamental behavioural and societal change required for seriously reduced corruption and significantly improved rule of law, then the CVM has failed to deliver such a reform (Dimitrov et al. 2014). Yet a counterfactual comparison with a situation where no EU pressure is applied suggests that in the absence of the CVM, corruption would have been far worse, certainly at least in Romania. While the CVM by itself thus does not achieve compliance without favourable domestic conditions, it appears a necessary condition for better compliance and corruption outcomes.

\section{Conclusions}

This article has examined the prospect for the EU to influence member states' anti-corruption policies through a novel mechanism of monitoring without enforcement, the CVM. We provide an empirical basis for pushing back against dismissing such a mechanism as inevitably ineffective. We coded the CVM reports' assessment of the extent to which Romania and Bulgaria have complied with the range of demands and recommendations for corruption control. The data suggest that monitoring can have an impact even without the threat of material 
sanctions. Compliance in Romania has been surprisingly good and consistently better than in Bulgaria (although it has deteriorated in recent years).

We argue that while the conditions for corruption control were generally not more favourable in Romania, the differences in the compliance records can be explained by the greater success in building effective domestic anti-corruption institutions in Romania. Evidence is starting to emerge that the CVM's impact on compliance is also matched by improvements in actual corruption levels. However, while Romania has improved, especially compared to Bulgaria, this achievement must be put in context: both countries still lag significantly behind other postcommunist EU members. Moreover, as developments in the late 2010s show, a reversal of progress is possible, and the fight against corruption remains vulnerable to obstruction by parliamentarians from across the political spectrum. Institution-building is therefore certainly not a sufficient condition for effective corruption control, but it can create favourable conditions that over time affect changes on the ground. Our finding about the importance of institutionbuilding qualify the finding that EU countries with a dedicated anti-corruption agency do not perform significantly better (Mungui-Pippidi 2013: 41). While a special agency by itself may indeed not lead to better outcomes, a stronger institutional infrastructure in combination with competent, dedicated and independent leadership and personnel may. At the same time, our analysis of Romania confirms that the role of the anticorruption agency depends on judicial independence (Mungui-Pippidi 2013: 41): without judicial independence, political interference with the anticorruption agency is difficult to avert.

The role of the CVM has been important in mandating institutional change, empowering civil society, and constraining efforts to reverse institution-building. The primary role of the CVM in constraining attempts to curtail the fight against corruption implies that we must not overstate the impact that the CVM can have on bringing about positive changes without domestic 
initiative. Instead, the CVM's impact is primarily that it limits the government's ability to undermine anti-corruption efforts openly, and especially to dismantle earlier institutional achievements. Crucially, the CVM does not owe its impact to material leverage acquired through the linkage that some member state governments have made with Romania's and Bulgaria's accession to Schengen. Instead, the CVM has mainly operated as an instrument of social pressure due to the strong legitimacy enjoyed by the EU among elites and publics. Our finding that the CVM had an impact on compliance in Romania despite its lack of sanctioning power offers additional evidence in support of existing scholarship on the social power of monitoring (e.g. Kelley and Simmons 2015).

Supplemental data for this article can be accessed at [link to source - publisher will add doi at proof]

\section{Acknowledgements}

For helpful comments, we would like to thank Antoaneta Dimitrova, Milada Vachudova, Matthias Matthijs, and three anonymous reviewers. This work was supported by the FP7 program of the EU (project MAXCAP) under grant agreement number 320115.

\section{Notes on contributors}

Corina Lacatus is Hillary Rodham Clinton Fellow at Queen's University Belfast

Ulrich Sedelmeier is Associate Professor (Reader) in International Relations at the London School of Economics and Political Science.

\section{Contact}

Corina Lactus c.lacatus@qub.ac.uk; Ulrich Sedelmeier u.sedelmeier@1se.ac.uk 


\section{References}

Bakker, R., C. de Vries, E. Edwards, L. Hooghe, S. Jolly, G. Marks, J. Polk, J. Rovny, M. Steenbergen and M.A. Vachudova (2015) 'Measuring Party Positions in Europe: The Chapel Hill Expert Survey Trend File, 1999 - 2010’ Party Politics 21(1):143-152.

Börzel, T.A., and T. Risse (2003) 'Conceptualising the Domestic Impact of Europe', in K. Featherstone and C. Radaelli (Eds.), The Politics of Europeanisation, Oxford: Oxford University Press, 55-78.

Dimitrov, G., K. Haralampiev, S. Stoychev, and L. Toneva-Metodieva (2014) The Cooperation and Verification Mechanism: Shared Political Irresponsibility, Sofia: St. Kliment Ohridski University Press.

Dimitrova, A.L. (2015) 'The Effectiveness and Limitations of Political Integration in Central and Eastern European Member States: Lessons from Bulgaria and Romania', MAXCAP Working Paper No. 10.

Dix, H. and C. Bogdan (2010) 'The Current Status of the Romanian National Integrity Agency', Konrad Adenauer Stiftung, Rule of Law Program South East Europe. available at http://www.kas.de/wf/doc/kas_20138-1522-2-30.pdf?100923140040.

Döring, H. and P. Manow (2019) Parliaments and governments database (ParlGov): Information on parties, elections and cabinets in modern democracies.

Epstein, R.A., and U. Sedelmeier (2008) 'Beyond Conditionality: International Institutions in Postcommunist Europe after Enlargement' Journal of European Public Policy 15(6):795-805.

Flash Eurobarometer (2015) 'The Cooperation and Verification Mechanism for Bulgaria and Romania: Second Wave', Flash Eurobarometer No. 406, January 2015.

Ganev, V.I. (2013) 'Post-Accession Hooliganism: Democratic Governance in Bulgaria and Romania after 2007' East European Politics \& Societies 27(1):26-44. 
Gateva, E. (2015) European Union Enlargement Conditionality, Basingstoke: Palgrave.

Grabbe, H. (2006) The EU's Transformative Power: Europeanization through Conditionality in Central and Eastern Europe, Basingstoke: Palgrave.

Hope, K. and T. Troev (2008) 'Bulgaria loses €250m EU funds', Financial Times, 26 November.

Innes, A. (2014) 'The Political Economy of State Capture in Central Europe' Journal of Common Market Studies 52(1):88-104.

Institute for Public Policy (2010) 'Effective mechanisms and practices for fighting corruption in the Black Sea region: Lessons learnt and further steps for Romania, Bulgaria, Turkey and Georgia' Bucharest: The Black Sea Trust for Regional Cooperation.

Jacoby, W. (2006) 'Inspiration, Coalition and Substitution: External Influences on Postcommunist Transformations’ World Politics 58(4):623-51.

Kartal, M. (2014) 'Accounting for the bad apples: the EU's impact on national corruption before and after accession' Journal of European Public Policy 21(6):941-59.

Kaufmann, D., A. Kraay and M. Mastruzzi (2010) The Worldwide Governance Indicators: Methodology and Analytical Issues, World Bank Policy Research Working Paper No. 5430.

Kelley, J.G. (2004) Ethnic Politics in Europe: The Power of Norms and Incentives, Princeton: Princeton University Press.

Kelley, J.G. and Simmons, B.A. (2015) 'Politics by Number: Indicators as Social Pressure in International Relations’ American Journal of Political Science 59(1):55-70.

Mendelski, M. (2012) 'EU-Driven Judicial Reforms in Romania: A Success Study?' East European Politics 28(1):23-42.

Mungiu-Pippidi, A. (2008) 'The EU as a transformation agent: lessons learned from governance reforms in East Central Europe' Journal of Constitutional Law in Eastern and Central Europe 15:233-65. 
Mungiu-Pippidi, A. (2013) 'The Good, the Bad and the Ugly: Controlling Corruption in the European Union' European Research Centre for Anti-corruption and State-building, Working Paper No. 35.

Papakostas, N. (2012) 'Deconstructing the Notion of EU Conditionality as a Panacea in the Context of Enlargement' L'Europe en Formation 364(2):215.

Schimmelfennig, F. and U. Sedelmeier (2004) 'Governance by Conditionality: EU Rule Transfer to the Candidate Countries of Central and Eastern Europe' Journal of European Public Policy 11(4):661-79.

Schimmelfennig, F. and U. Sedelmeier (2005) 'Conceptualizing the Europeanization of Central and Eastern Europe', in F. Schimmelfennig and U. Sedelmeier (Eds.), The Europeanization of Central and Eastern Europe, Ithaca: Cornell University Press, 1-28. Schoenman, R. (2014) Networks and Institutions in Europe's Emerging Markets, Cambridge: Cambridge University Press.

Sedelmeier, U. (2008) 'After Conditionality: Post-accession Compliance with EU Law in East Central Europe' Journal of European Public Policy 15(6):806-25.

Sedelmeier, U. (2014) 'Anchoring Democracy from Above? The European Union and Democratic Backsliding in Hungary and Romania after Accession' Journal of Common Market Studies 52(1):105-21.

Sedelmeier, U. (2017) 'Political Safeguards against Democratic Backsliding in the EU: the Limits of Material Sanctions and the Scope of Social Pressure' Journal of European Public Policy 24(3):337-51.

Sedelmeier, U and C. Lacatus (2016) ‘Compliance with the European Union's Anti-Corruption Conditions in the 'Cooperation and Verification Mechanism': Why Is Romania Better than Bulgaria?', MAXCAP Working Paper No. 28, Berlin: Freie Universität Berlin. 
Spendzharova, A.B. and M.A. Vachudova (2012) 'Catching Up? Consolidating Liberal Democracy in Bulgaria and Romania after EU Accession' West European Politics 35(1):39-58.

Tanasoiu, C., and M. Racovita (2012) 'Post-Accession (Anti-) Corruption Record in Romania and Bulgaria' L'Europe en Formation 364(2):243.

Toneva-Metodieva, L. (2014) 'Beyond the Carrots and Sticks Paradigm: Rethinking the Cooperation and Verification Mechanism Experience of Bulgaria and Romania' Perspectives on European Politics and Society 15(4):534-51.

Vachudova, M.A. (2005) Europe Undivided: Democracy, Leverage and Integration After Communism, Oxford: Oxford University Press. 
Figure 1: Compliance with the CVM in Bulgaria and Romania (average of all anticorruption benchmarks)

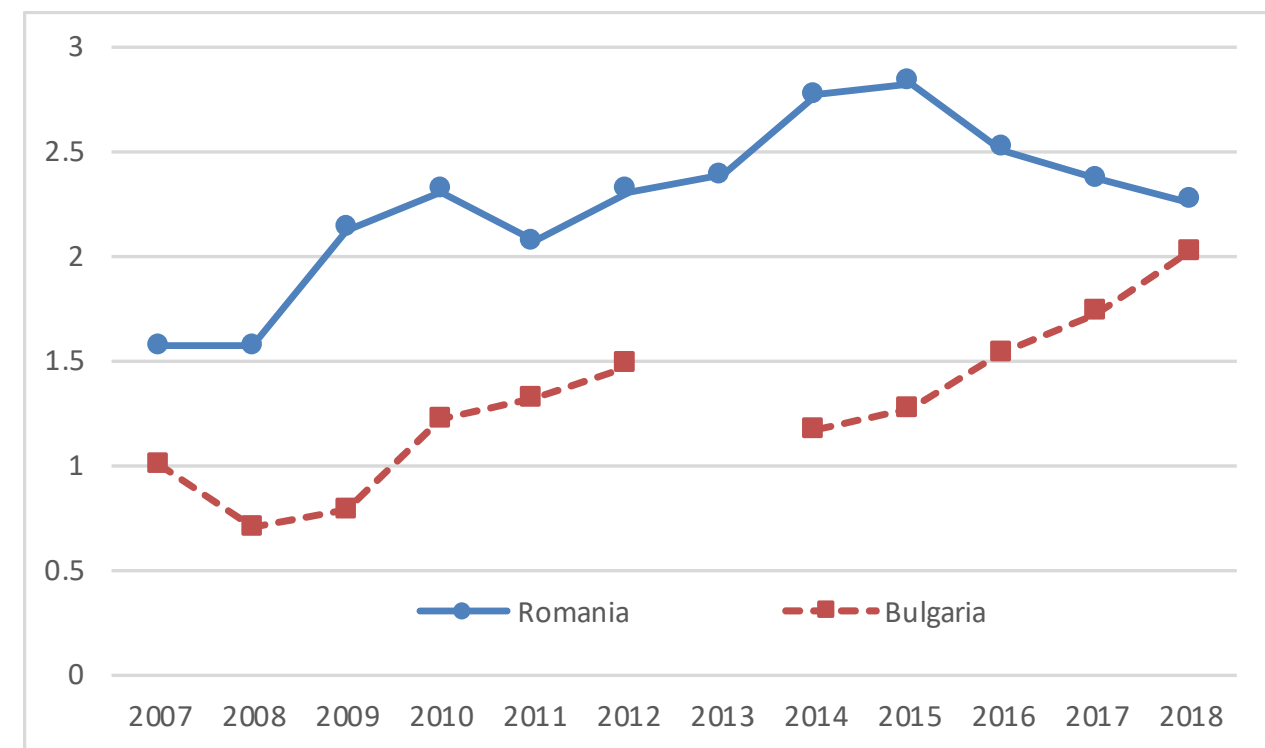

Source: Own coding of the CVM reports.

\section{Figure 2: Public opinion about EU membership}

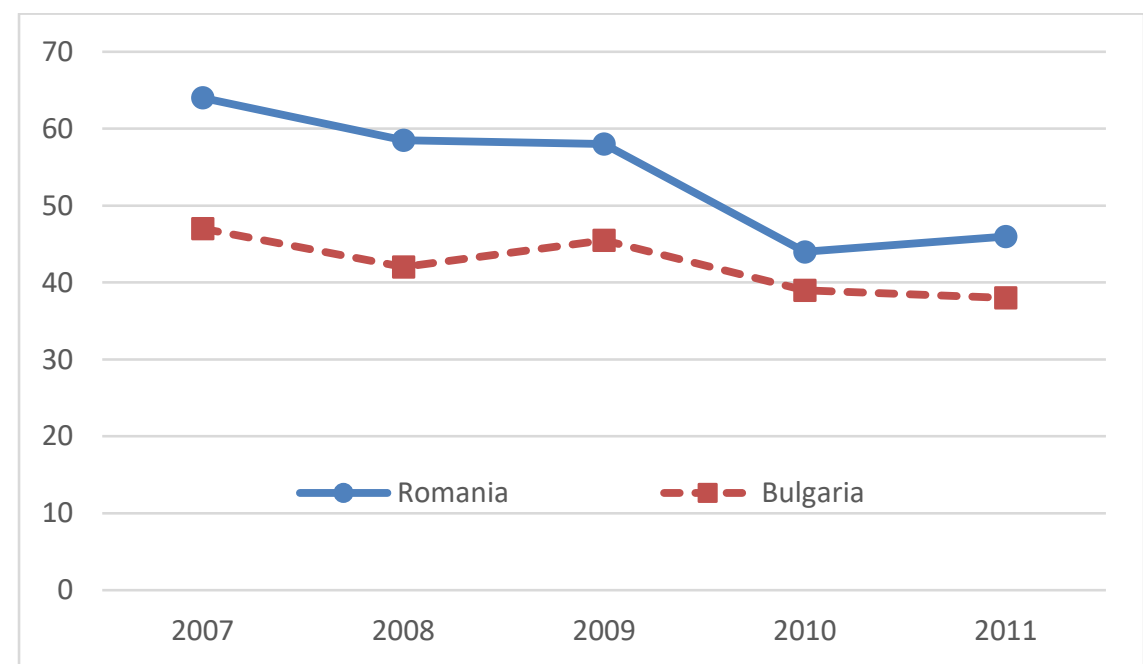

Note: Percentage of net support for EU membership ('EU membership is a good thing' minus 'a bad thing'), annual averages for bi-annual reports from 2007-2008.

Source: Own calculation based on the Eurobarometer 2007-2011. 


\section{Figure 3: Government attitudes towards European integration}

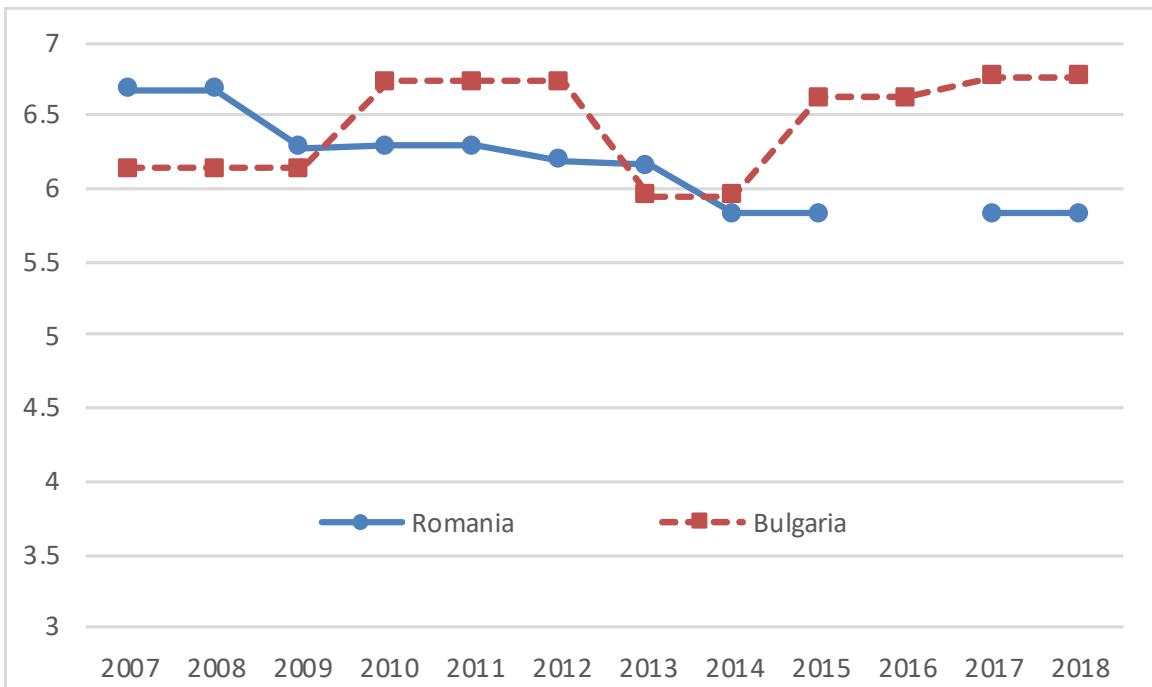

Note: Attitudes towards European integration on a scale from 1 (strongly opposed) to 7 (strongly in favour). For coalition governments, the attitudes of individual coalition parties are weighted by their share of the seats that the government holds in parliament.

Source: Authors' calculation based on the Chapel Hill Expert Survey (Bakker et al. 2015); government composition and parliamentary seats are taken from the ParlGov database (Döring and Manow 2015).

\section{Figure 4: Government Left-Right (economic) orientation in Bulgaria and Romania}

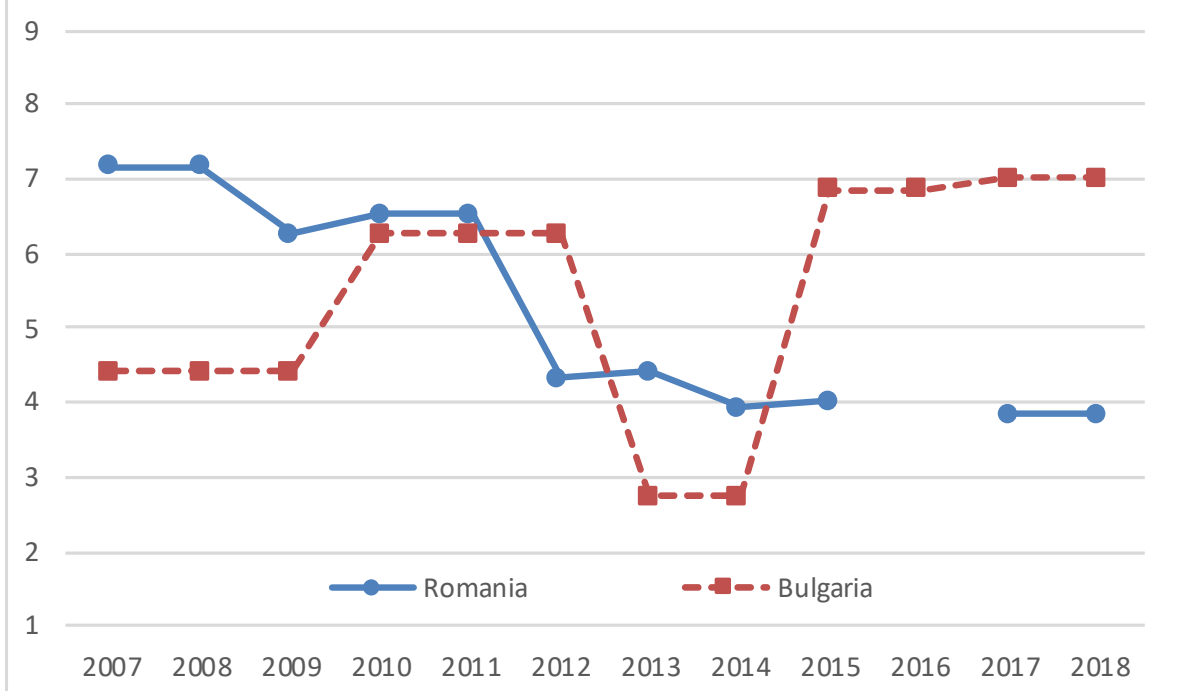

Note: Governments' Left/Right orientation on a scale from 1 (extreme left) to 10 (extreme right). For coalition governments, the orientations of individual coalition parties are weighted by their share of the seats that the government holds in parliament.

Source: Authors' calculation based on the Chapel Hill Expert Survey (Bakker et al. 2015); government composition and parliamentary seats are taken from Döring and Manow (2019). 
Figure 5: Strength of Civil Society and Independence of the Media

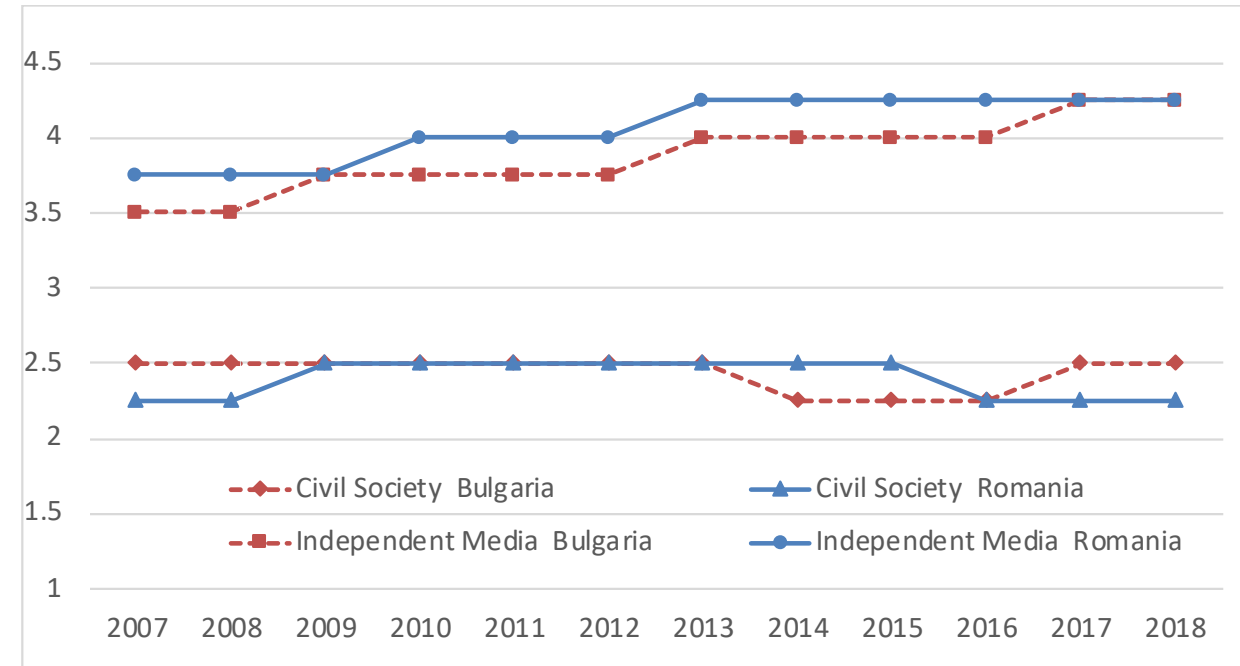

Note: Scores from 1 (highest) to 7 (lowest).

Source: Freedom House Nations in Transit.

Figure 6: Corruption Control in Romania and Bulgaria

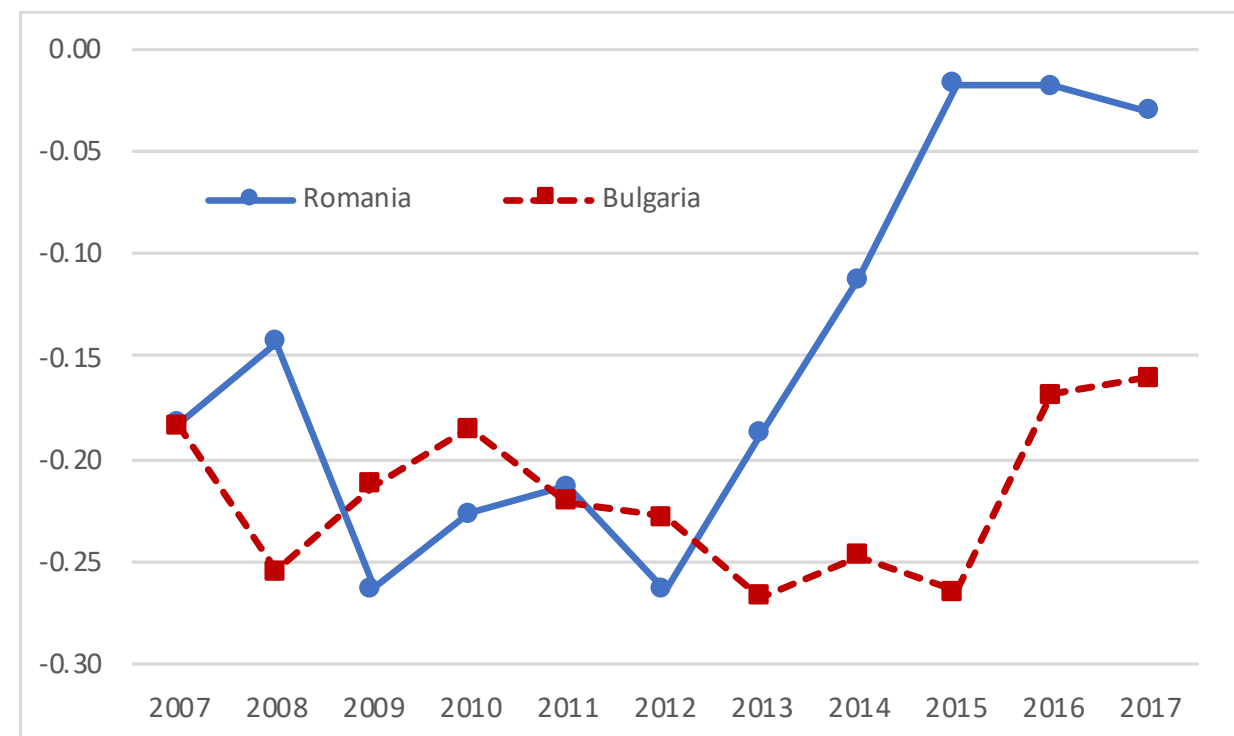

Note: Scores from 2.5 (highest) to -2.5 (lowest)

Source: Kaufmann et al. (2015) 